\title{
Annotated checklist of the amphibians and reptiles of the Santander highland, Colombia
}

\author{
Diego A. Pérez-Rojas, Diego Escamilla-Quitián, María Fernanda Estupiñan-Tibaduiza, Juan E. \\ Carvajal-Cogollo
}

Grupo de Investigación Biodiversidad y Conservación. Museo de Historia Natural "Luis Gonzalo Andrade", Programa de Biología, Universidad Pedagógica y Tecnológica de Colombia, Av. Central del Norte \# 115-39, Tunja, Boyacá, 150001, Colombia.

Corresponding author: Juan E. Carvajal-Cogollo, juancarvajalc@gmail.com

\begin{abstract}
We characterize the amphibian and reptile fauna from four habitats of the Andean region of the department of Santander, Colombia. Eight species were recorded, including four amphibians and four reptiles. The family Hylidae was represented by two species and had the greatest abundance of individuals at 241. Among reptiles, the family with the greatest diversity was the Colubridae, with two species, but the Dactyloidae had the greatest abundance, with seven individuals. The grassland habitat exhibited the greatest diversity, with five species found, and it was the habitat with the greatest abundance of individuals, with 242 individuals obtained. The habitat with the least diversity and abundance was cropland, which had no species recorded.
\end{abstract}

\section{Keywords}

Andean region, ecological aspect, fragmented habitat, herpetofauna, species distribution, taxonomic diversity.

Academic editor: Ross MacCulloch | Received 9 January 2020 | Accepted 11 April 2020 | Published 22 May 2020

Citation: Pérez-Rojas DA, Escamilla-Quitián D, Estupiñan-Tibaduiza MF, Carvajal-Cogollo JE (2020) Annotated checklist of the amphibians and reptiles of the Santander highland, Colombia. Check List 16 (3): 611-620. https://doi.org/10.15560/16.3.611

\section{Introduction}

The Andean forests are one of the most important vegetation formations in Colombia due to the ecosystem services they provide. However, they are also among the most threatened ecosystem, due to their changes in land use to productive systems mainly agriculture and livestock (Etter et al. 2006). Endemic species are numerous, and some of their populations are naturally small and fragile due to fragmentation and habitat loss, which has been mainly caused by the development of livestock and agriculture production (Rangel-C. 1997). The fragmentation of these forests affects biodiversity, both positively and negatively; it decreases vegetation cover of the forest, changes species diversity, population densities, and impacts ecosystem functionality (Rangel-C. 2000).

The herpetofauna of the Colombian Andes is influenced by changes in their habitats and the physiological requirements of species, including thermoregulation characteristics of reptiles (Pough et al. 2001). There have been many investigations on Andean amphibians and reptiles on these topics (Méndez-Narváez 2014). Twentyone species of amphibians (Ardila-Robayo and AcostaGalvis 2000; Lynch and Suárez-Mayorga 2002) and 10 species of reptiles (Castaño-Mora et al. 2000) have been reported from the Cordillera Oriental of Colombia. 
From the Bogotá savannah, Lynch and Rengifo (2001) and Ariza et al. (2010) recorded 13 amphibian and eight reptile species; Medina-Rangel and López-Perilla (2014) recorded seven species of anuran and three reptile species. However, in large areas of the Cordillera Oriental, mainly the departments of Boyacá and Cundinamarca, there is a lack of studies on the composition, structure, and effects of habitat transformation on the herpetofauna.

As inventories provide basic data, which are useful for decision-making, our goal is to provide an annotated list of the herpetofauna in the Santander highland, north of the Cordillera Oriental, Colombia.

\section{Methods}

Study area. The study area, at 2600-2800 $\mathrm{m}$ above sea level, was north of the Cordillera Oriental, near the municipality of Sucre, in the department of Santander (Fig. 1). The study area is composed of a mosaic of natural, semi-natural, and anthropogenic elements. The regional climate is bimodal-tetraseasonal, with an average rainfall of 2000-2114 mm (Rangel-C. 1997), and an average temperature of $16-17{ }^{\circ} \mathrm{C}$. The terrain is rough, with steep slopes that exceed $50 \%$. The dominant topography in the study area are grasslands, which are dedicated to cattle grazing. There are also patches of forests, from passive regeneration that has occurred over the last 25 years. Perennial crops, mainly blackberry (Morus nigra L.), are also cultivated.

Research and sampling design. We chose four habitats for our study:

1. Large forest fragment $\left(05^{\circ} 51^{\prime} 56^{\prime \prime} \mathrm{N}, 073^{\circ} 54^{\prime} 37^{\prime \prime} \mathrm{W}\right.$ and $\left.05^{\circ} 51^{\prime} 50^{\prime \prime} \mathrm{N}, 073^{\circ} 54^{\prime} 38^{\prime \prime} \mathrm{W}\right)$. This area exceeds 100 ha (Fig. 2A), with a high floristic diversity and complex vegetative structure. Trees exceed $15 \mathrm{~m}$ in height, and the canopy is closed. Herbaceous groundcover extends over $20 \%$ of the area, shrubs covers $30 \%$, and trees cover $40 \%$. The soil has an uppermost leaf-litter layer, with
$80 \%$ coverage. The average grass height is $10 \mathrm{~cm}$. Species of Melastomataceae and Clusiaceae are dominant, followed by Myrtaceae, Piperaceae, Rubiaceae, Sapindaceae, and Sapotaceae.

2. Small forest fragment $\left(05^{\circ} 51^{\prime} 41^{\prime \prime} \mathrm{N}, 073^{\circ} 54^{\prime} 19^{\prime \prime} \mathrm{W}\right.$ and $\left.05^{\circ} 51^{\prime} 46^{\prime \prime} \mathrm{N}, 073^{\circ} 54^{\prime} 12^{\prime \prime} \mathrm{W}\right)$. This is a linear fragment of forest less than 20 ha, which extends along a creek. The canopy is semi-open (Fig. 2B); groundcover covers $80 \%$ of the area, shrubs cover $20 \%$, underbrush covers $40 \%$, and trees cover $30 \%$. Leaf litter covers $30 \%$ of the ground, and the average grass height is $5 \mathrm{~cm}$. Dominant families are Adoxaceae, Aquifoliaceae, Aquifoliaceae, Araliaceae, Gesneriaceae, Melastomataceae, Myrtaceae, Clusiaceae, Piperaceae, Rubiaceae, Sapindaceae, and Sapotaceae.

3. Grassland $\left(05^{\circ} 52^{\prime} 20^{\prime \prime} \mathrm{N}, 073^{\circ} 54^{\prime} 39^{\prime \prime} \mathrm{W}\right.$ and $05^{\circ} 52^{\prime}$ $\left.27^{\prime \prime} \mathrm{N}, 073^{\circ} 54^{\prime} 10^{\prime \prime} \mathrm{W}\right)$ represent the most extensive habitat in the study area (Fig. 2C). Herbaceous groundcover exceeds $90 \%$, with a median height of $10 \mathrm{~cm}$. Isolated trees cover less than $10 \%$ of the area.

4. Perennial cropland $\left(05^{\circ} 52^{\prime} 01^{\prime \prime} \mathrm{N}, 073^{\circ} 54^{\prime} 37^{\prime \prime} \mathrm{W}\right.$ and $05^{\circ} 52^{\prime} 06^{\prime \prime} \mathrm{N}, 073^{\circ} 54^{\prime} 33^{\prime \prime} \mathrm{W}$ ) is represented in the study area by blackberry crops with large expanses of open areas (Fig. 2D). There is no stratification, and the ground is completely bare due to the constant erosion of the soil.

In each of these four habitats, two plots were set out. Each plot was a $100 \times 50 \mathrm{~m}$ rectangle. Random routes, each $100 \mathrm{~m}$ long, were made at each plot, using visual encounter surveys (Crump and Scott 1994; Angulo et al. 2006). Each route visit lasted 160 hours. The sampling effort was 120 hours per person for each habitat $(=480$ hours per person).

Between June 2017 and February 2018, surveys were carried out three times, each time during both day and night. Microhabitats were closely examined and included leaf litter, fallen tree trunks, the undersides of rocks, and branches up to $3 \mathrm{~m}$ above ground. For each species, several individuals were collected for identification, which

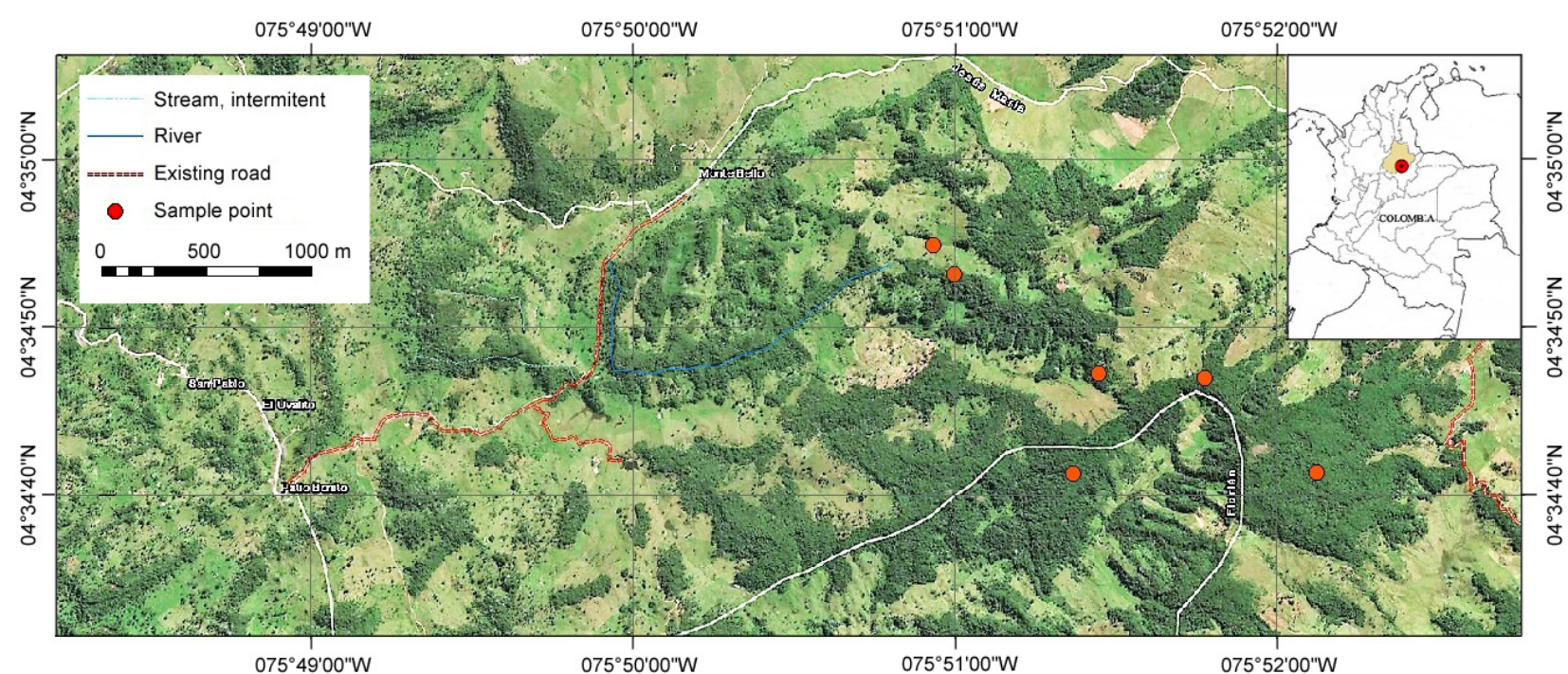

Figure 1. Study area in the municipality of Sucre, department of Santander, Colombia. The study area is north of the Cordillera Oriental at 2600-2800 m a.s.l. 


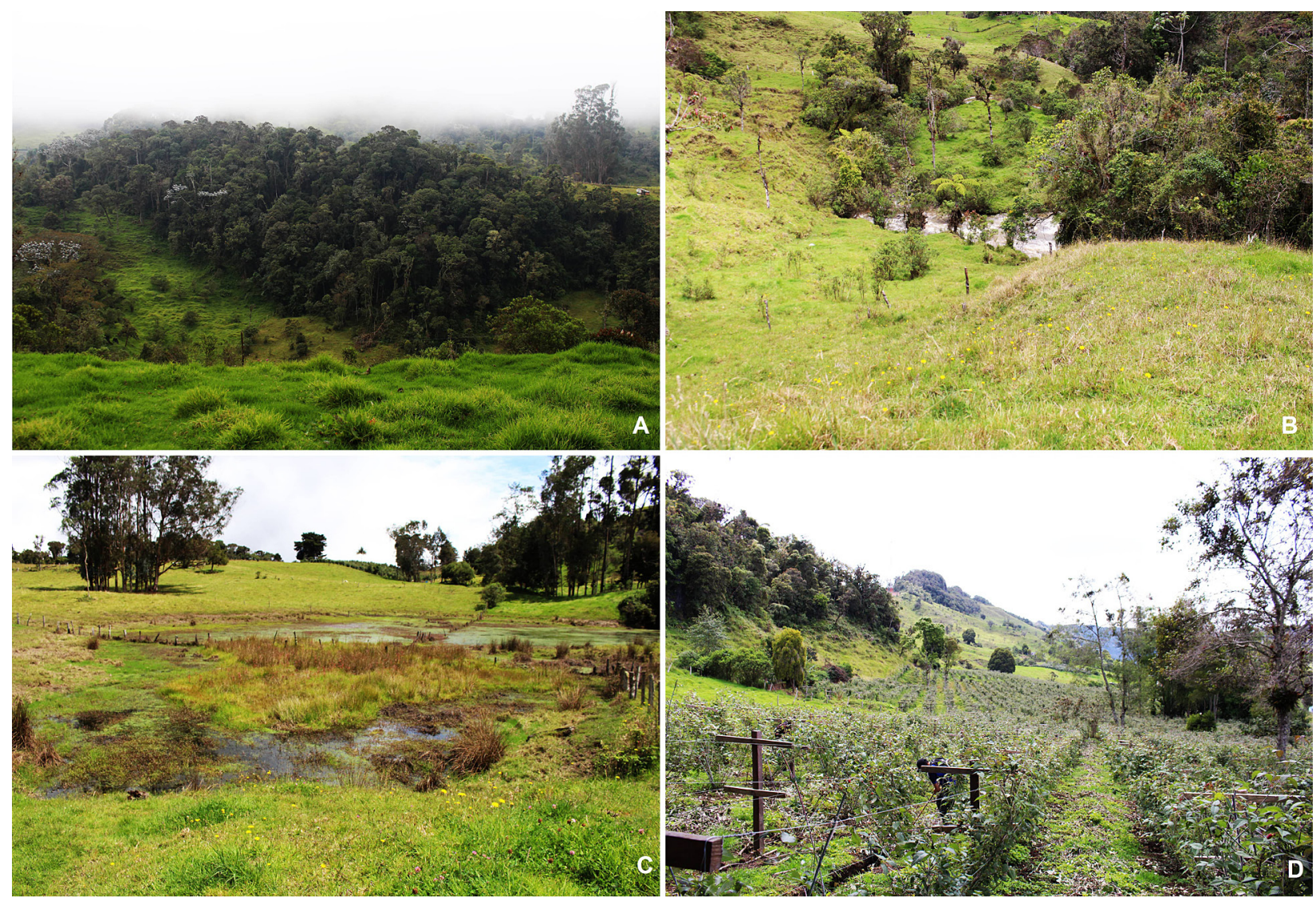

Figure 2. The four habitats in the study area. A. Large forest fragment. B. Small forest fragment. C. Grassland. D. Blackberry crop.

was achieved using taxonomic keys and other literature (Sánchez-Pacheco et al. 2012; Passos and Lynch 2010). Specimens were captured by hand, euthanized using a lethal dose of anesthetic, preserved in ethanol (70\%), and deposited in the vertebrate collection of the Museo de Historia Natural "Luis Gonzalo Andrade", Universidad Pedagógica y Tecnológica de Colombia. Collections were made under permit number 724/2014 issued by the Autoridad Nacional de Licencias Ambientales. Some individuals were identified, photographed, and immediately released.

The number of specimens collected and the number of times each species was encountered are shown in Table 1. The number of habitats in which each species was found is characterized as wide ( $\geq 2$ habitats) or restricted $(<2$ habitats).

Matrices were built to show the composition and abundance of species. The sampling effort for each taxonomic group in the study area was plotted and alpha diversity was calculated from non-parametric estimators using the Jack 1 Mean, which estimates the richness of individuals in heterogeneous habitats, and using the Bootstrap Mean index, which estimates the rich variety of species without overestimating it, as this is not influenced by rare species (Magurran 2004). These analyses were performed using the EstimateS statistical program v. 9.20 (Colwell 2018). To compare the species abundances, rank abundance graphs were made from the base logarithms for eight of the species.

\section{Results}

Eight species were recorded: four amphibians and four reptiles. The amphibians belong to two orders, three families, and four genera. The family with the greatest diversity was Hylidae, with two species. The reptiles belong in two orders, three families, and four genera, and the reptilian family with greatest diversity was Colubridae, with two species (Table 1). Grasslands supported the greatest richness with five species (Table 1). The small and large forest fragments each had two species. The most abundant amphibian species was Dendropsophus molitor (Schmidt, 1857), with 223 individuals, while the most abundant reptile was Anolis nicefori Barbour, 1932, with 10 individuals (Table 1).

Table 1. Richness and abundance of species in four high-elevation habitats in Sucre, Santander department, Cordillera Oriental, Colombia.

\begin{tabular}{lcccc}
\hline Species & $\begin{array}{c}\text { Large } \\
\text { forest }\end{array}$ & $\begin{array}{c}\text { Small } \\
\text { forest }\end{array}$ & $\begin{array}{c}\text { Grass- } \\
\text { lands }\end{array}$ & $\begin{array}{c}\text { Perennial } \\
\text { cropland }\end{array}$ \\
\hline Dendropsophus molitor (Schmidt, 1857) & 0 & 0 & 223 & 0 \\
Hyloscirtus piceigularis (Ruiz \& Lynch, 1982) & 0 & 18 & 0 & 0 \\
Pristimantis bogotensis (Peters, 1863) & 2 & 0 & 0 & 0 \\
Bolitoglossa adspersa (Peters, 1863) & 9 & 0 & 0 & 0 \\
Riama striata (Peters, 1863) & 0 & 0 & 6 & 0 \\
Anolis nicefori Barbour, 1932 & 0 & 3 & 7 & 0 \\
Atractus marthae Meneses-Pelayo \& Passos, 2019 & 0 & 0 & 4 & 0 \\
Erythrolamprus epinephelus (Cope, 1862) & 0 & 0 & 2 & 0 \\
\hline Total & $\mathbf{1 1}$ & $\mathbf{2 1}$ & $\mathbf{2 4 2}$ & $\mathbf{0}$ \\
\hline
\end{tabular}


For amphibians, the sample representativeness exceeded $80 \%$. The species accumulation shows that one or two additional species might be present, according to the Bootstrap and Jack 1 estimators (five and six species, respectively). We deemed species rare if only one or two individuals were found. Only one rare amphibian species, Pristimantis bogotensis (Peters, 1863), was found during the survey. For reptiles, the sample representativeness also exceeded $80 \%$, and increased sampling effort might add a few more species. Rare species decreased as sampling increased. The rarest species, Erythrolamprus epinephelus (Cope, 1862), was represented by only two individuals found during the entire survey.

The rank abundance graph (Fig. 3) shows that $D$. molitor is more abundant than other species of amphibians, which can be explained by its resistance to stressors caused by anthropogenic activities (Lynch and Rengifo 2001). Conversely, snakes were rare in the study area.

Class Amphibia

Order Anura

Family Hylidae

Subfamily Dendropsophinae

Genus Dendropsophus Fitzinger, 1843

\section{Dendropsophus molitor (Schmidt, 1857)}

Materials examined. COLOMBIA $\bullet 5$ adults $q, 3$ adults ऽ; Santander, municipality of Sucre, La Pradera, La Playa; 0552'19"N, 07354'41"W, 2574 m a.s.l.; 25 Jun. 2017; Juan Carvajal leg.; UPTC-Am 1000 to UPTC-Am $1007 \cdot 1$ adult ${ }^{\lambda}$; Santander, municipality of Sucre, La Pradera, Casa Loma; 05 $52^{\prime} 00^{\prime \prime} \mathrm{N}, 073^{\circ} 54^{\prime} 36^{\prime \prime} \mathrm{W}, 2574$ m a.s.1.; 23 Jun. 2017; María Estupiñan leg.; UPTC-Am $1008 \cdot 5$ adults ${ }^{\top}$; Santander, municipality of Sucre, La

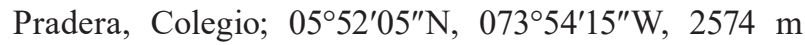
a.s.l.; 25 Jun. 2017; Diego Pérez leg.; UPTC-Am 1009 to UPTC-Am 10091011, UPTC-Am 0971, UPTC-Am 10090973.

Identification. Our specimens were easily identified as D. molitor by the following: distance from nostrils to end of the snout half the distance from end of snout to eye; eyes small, non-prominent, diameter equal to distance from eye to nostril; tympanum prominent, half the diameter of eye; and relative finger length $\mathrm{I}<\mathrm{II}<\mathrm{IV}<\mathrm{III}$, with fourth finger longer than second (Guarnizo et al. 2014).

Remarks. We found Dendrosophus molitor to have the largest populations of any amphibians in the study area. This species was locally restricted to pastures and areas near crops. The preferred microhabitat was grassy areas, near water bodies (Fig. 2C). Specimens varied widely in color, from green to yellow and with mottled tones (Fig. 4). The population in the study area is ideal for studies on thermal tolerances, intrapopulation polymorphisms, and ecology, ethology, and reproduction.

Subfamily Cophomantinae

Genus Hyloscirtus Peters, 1882

\section{Hyloscirtus piceigularis (Ruiz \& Lynch, 1982)}

Materials examined. COLOMBIA • 1 adult $\widehat{o}$; Santander, municipality of Sucre, La Pradera, Tequendama; 05 $51^{\prime} 47^{\prime \prime} \mathrm{N}, 073^{\circ} 54^{\prime} 40 \mathrm{~W}, 2574 \mathrm{~m}$ a.s.1.; 23 Jun. 2017; Diego Escamilla leg.; UPTC-Am $1012 \cdot 1$ adult $\widehat{\jmath}$; Santander, municipality of Sucre, La Pradera, Peña Bonita river; $05^{\circ} 51^{\prime} 43^{\prime \prime} \mathrm{N}, 073^{\circ} 54^{\prime} 16^{\prime \prime} \mathrm{W}, 2574 \mathrm{~m}$ a.s.1.; 20 Aug. 2017; Juan Carvajal leg.; UPTC-Am 0972.

Identification. Our specimens were easily identified as $H$. piceigularis based on: finger webbing extending to base of distal subarticular tubercle of finger IV; ulnar, tarsal and supra-anal folds with red edge, yellow bottom base, and cream top; tympanum covered by skin without modifications; and mental gland present in males (RuizCarranza and Lynch 1982).

Remarks. We recorded 18 individuals, even though the population may be larger, given the auditory record and the capacity of this species for concealment. Hyloscirtus piceigularis was found in the small forest fragment, in a ravine (Fig. 2B) and had mossy rocks as their preferred

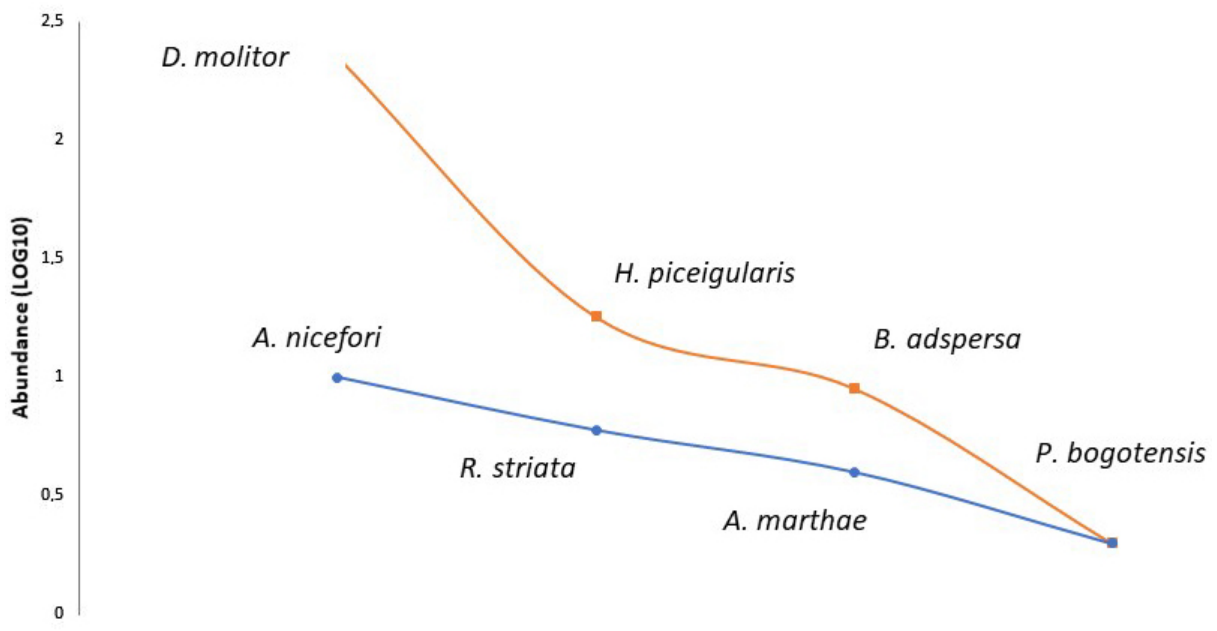

Figure 3. Behavior of the abundance of amphibian and reptile species in high-mountain habitats in the Santander highland, north of the Cordillera Oriental, Colombia. 

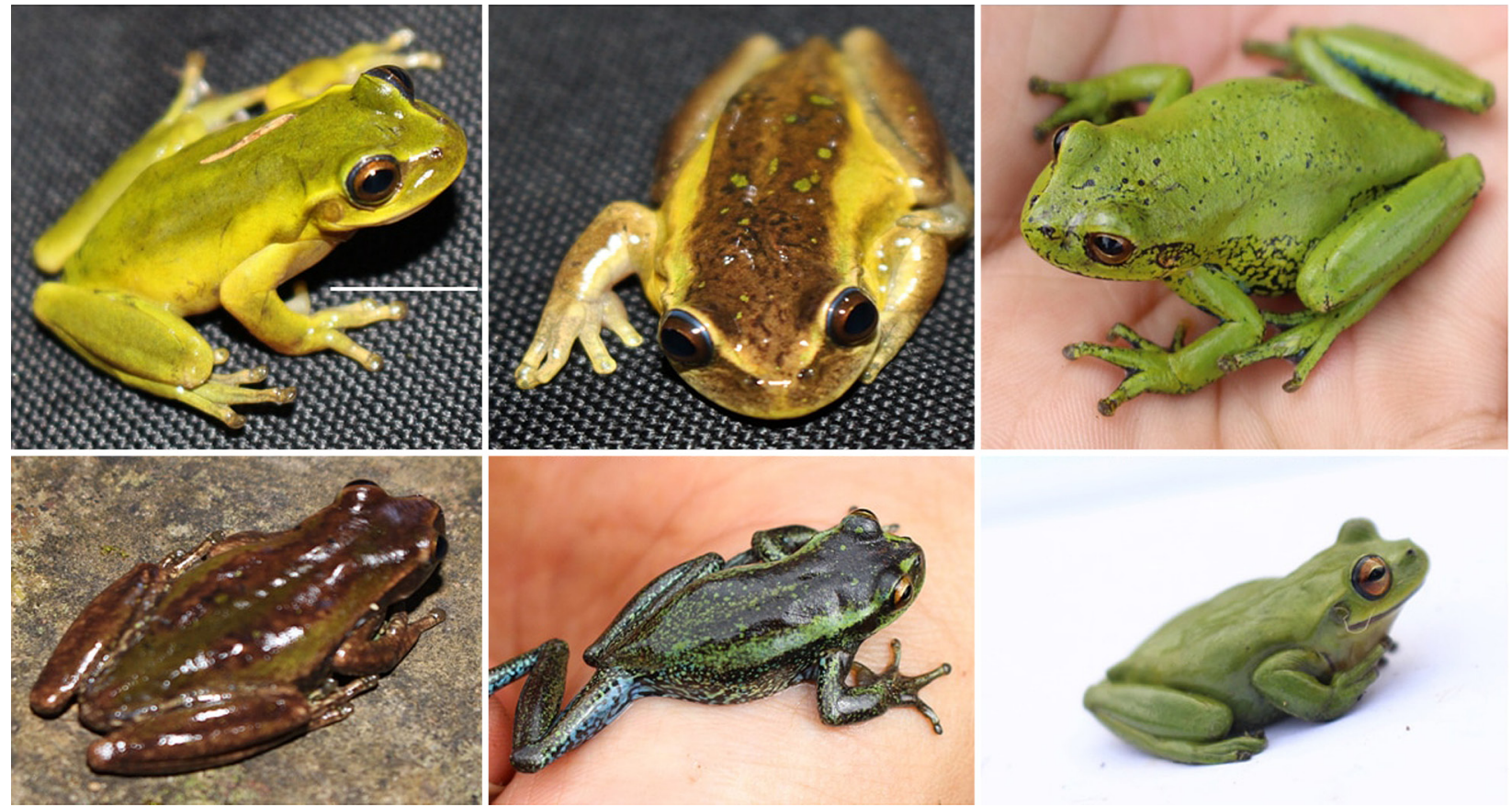

Figure 4. Color variation of Dendropsophus molitor. Scale bar $=9 \mathrm{~mm}$.

microhabitat (Fig. 5). Animals were active both during the day and at night. Tadpoles at various stages were found in backwaters and other lotic waterbodies during the dry season in February The study area lies between the species' northernmost occurrence, in the municipality of Encino, and its southernmost occurrence, in the department of Cundinamarca. We extend the distribution of the species approximately $100 \mathrm{~km}$, from the type locality in the municipality of Encino.

Family Craugastoridae

Subfamily Ceuthomantinae

Genus Pristimantis Jiménez de la Espada, 1870

Pristimantis bogotensis (Peters, 1863)

Materials examined. COLOMBIA $\bullet 1$ adult $\widehat{\partial}$; Santander, municipality of Sucre, La Pradera, Fontibón; $05^{\circ}$
51'53" N, 073 $54^{\prime} 37^{\prime \prime}$ W, 2574 m a.s.1.; 23 Jun. 2017; Diego Escamilla leg.

Identification. Our specimens were identified as $P$. bogotensis based on the characters given by Werner (1916): tympanum transparent, half the diameter of the eye; supratympanic fold distinct; toe webbing basal.

Remarks. This is a rare species; we recorded only two individuals, both from the interior of the large forest fragment (Fig. 2A). The preferred microhabitat of $P$. bogotensis was low branch, close to the ground. This species was nocturnal.

Order Caudata

Family Plethodontidae

Subfamily Hemidactyliinae

Genus Bolitoglossa Duméril, Bibron \& Duméril, 1854
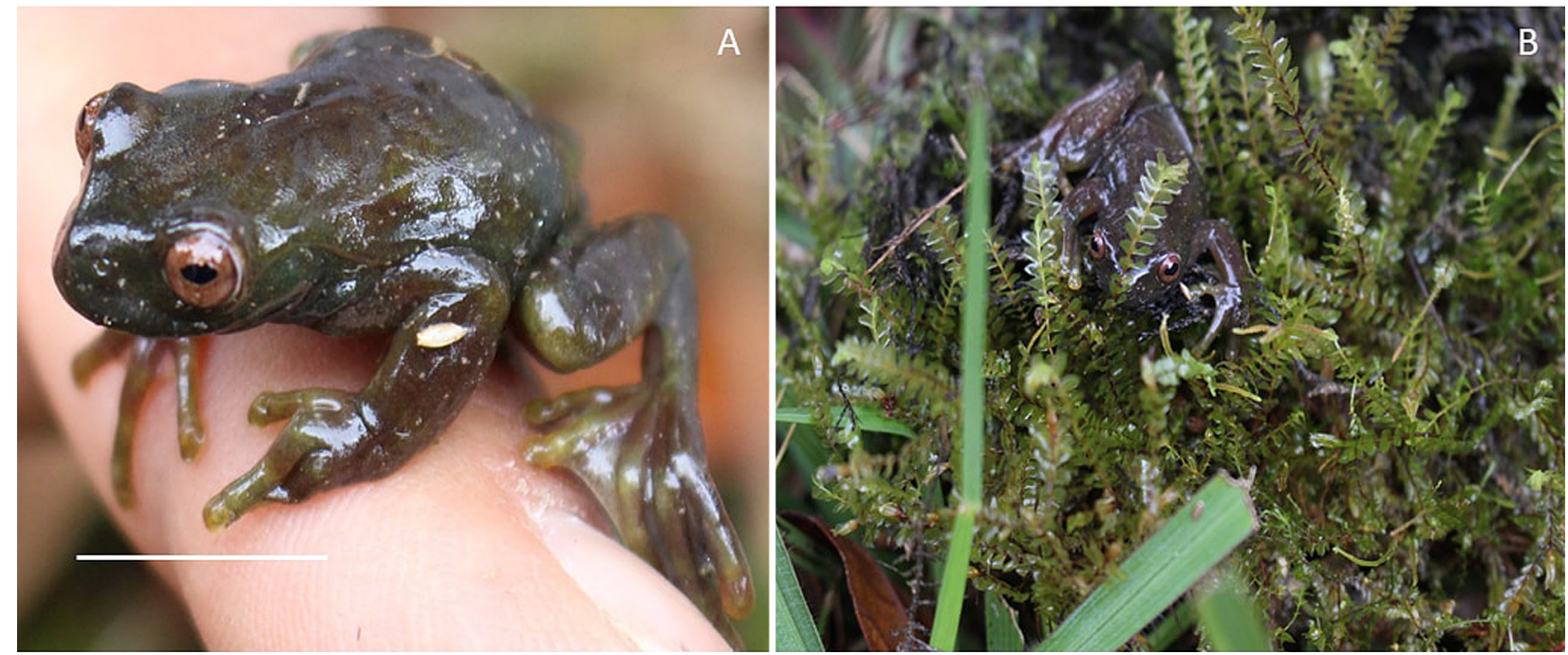

Figure 5. Hyloscirtus piceigularis. A. Male individual, scale bar $=14 \mathrm{~mm}$, head length. B. Camouflage in moss. 


\section{Bolitoglossa adspersa (Peters, 1863)}

Materials examined. COLOMBIA • 4 adults $\hat{\jmath}$; Santander, municipality of Sucre, La Pradera, Fontibón; 05 51'53" N, 073 54'37" W, 2574 m a.s.1.; 23 Jun. 2017; Diego Pérez leg.; UPTC-Am 1013 to UPTC-Am 1016.

Identification. Our specimens were identified as $B$. adspersa based on size of the males and females (snoutvent length $47 \mathrm{~mm}$ and $54 \mathrm{~mm}$, respectively), about three times the distance from tip of snout to gular fold; limbs short, not meeting when adpressed; fingers and toes very short and broad, truncate, and webbed, with the tips free; carpal or tarsal tubercules absent; and tail cylindrical, shorter than total length of the body.

Remarks. This species was restricted to the large forest fragment (Fig. 2A) and occurred in several microhabitats, but especially on leaves. One or two individuals were sighted per leaf (Fig. 6).

Class Reptilia

Order Squamata

Infraorder Iguania

Family Dactyloidae
Genus Anolis Daudin, 1802

\section{Anolis nicefori Barbour, 1932}

Materials examined. COLOMBIA • 1 adult $\widehat{\jmath}$; Santander, municipality of Sucre, La Pradera, La Playa; $05^{\circ}$ 52'19"N, 07354'41"W, 2574 m a.s.1.; 25 Jun. 2017; María Estupiñan leg.; UPTC-R 0599 • 1 adult ${ }^{\top}$; Santander, municipality of Sucre, La Pradera, Peña Bonita river; $05^{\circ}$ $51^{\prime} 43^{\prime \prime} \mathrm{N}, 073^{\circ} 54^{\prime} 16^{\prime \prime} \mathrm{W}, 2574$ m a.s.l.; 20 Aug. 2017; Juan Carvajal, Diego Pérez, Diego Escamilla and María Estupiñan leg.; UPTC-R 0590.

Identification. Our specimens were identified as A. nifefori based on: small dorsal scales, in 21-34 rows; small head plates, with interparietal scale much shorter than width of head between orbits; and subdigital lamellae 16-20 (Lazell 1969).

Remarks. This species occurred in the small forest fragment and in the grassland. Individuals were observed at night, for the first time, resting on leaves and small branches. Specimens varied in color, being various shades of green, yellow, and blue (Fig. 7). This variability in color has not been previously reported for this species.
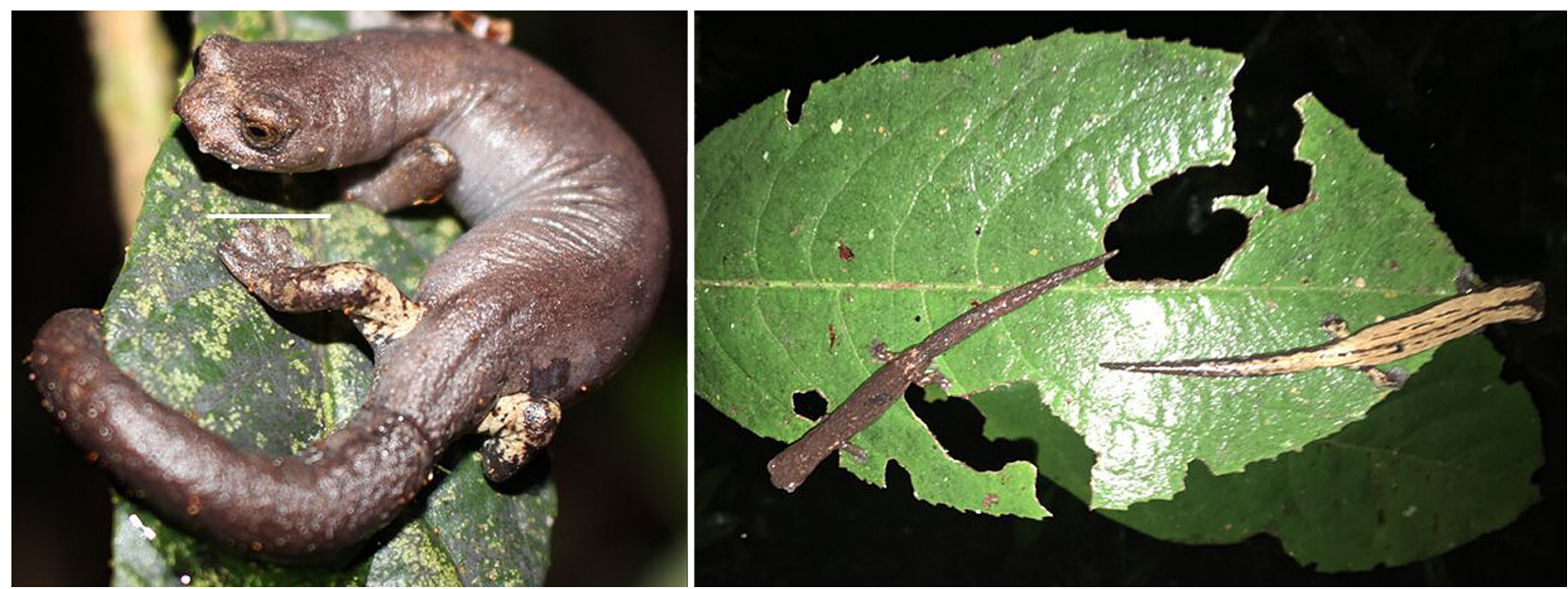

Figure 6. Bolitoglossa adspersa. Scale bar (on left) $=13 \mathrm{~mm}$
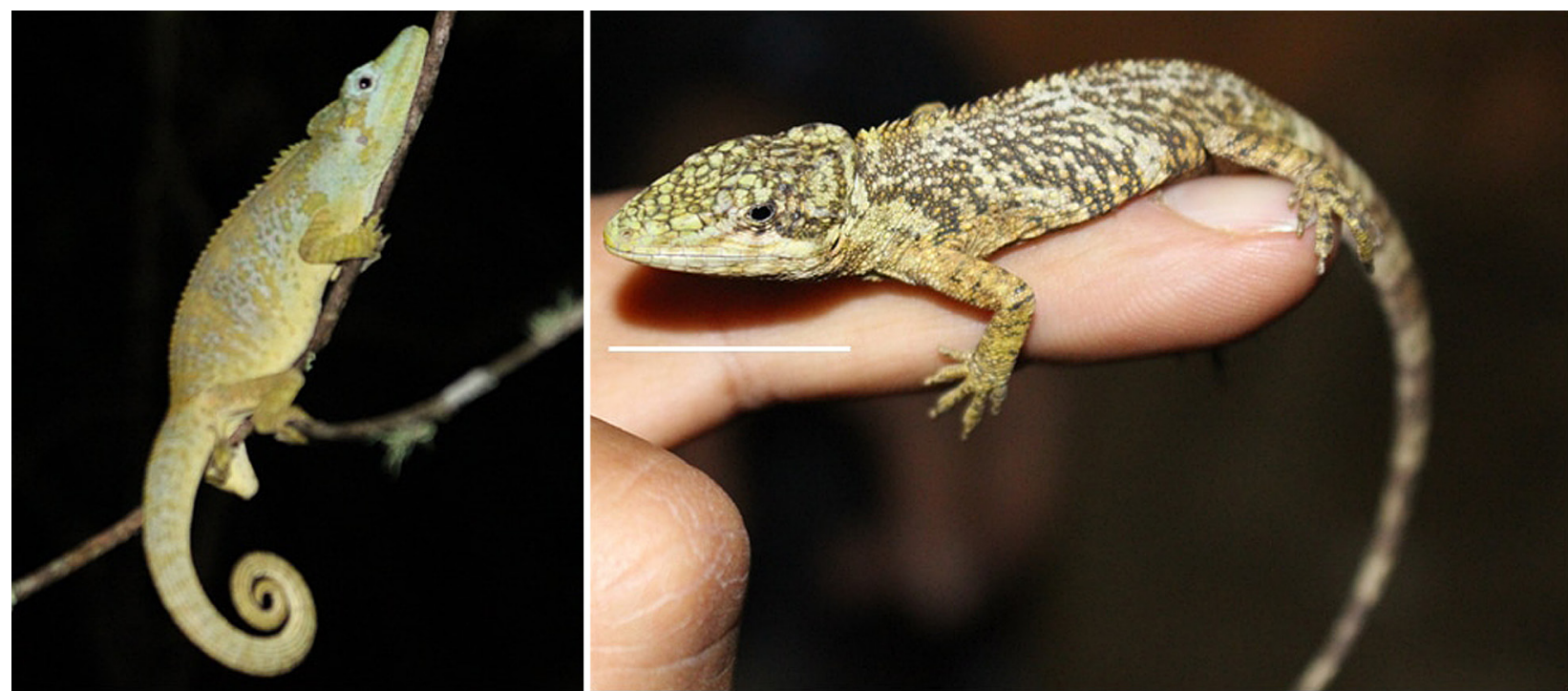

Figure 7. Color variation of Anolis nicefori. Scale bar (on right) $=20 \mathrm{~mm}$. 
Infraorder Scincomorpha

Family Gymnophthalmidae

Subfamily Cercosaurinae

Genus Riama Gray|, 1858

\section{Riama striata (Peters, 1863)}

Materials examined. COLOMBIA $\cdot 3$ adults $1 \lesssim 2 q, 3$ juveniles; Santander, municipality of Sucre, La Pradera,

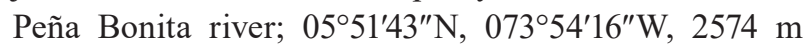
a.s.l.; 20 Aug. 2017; Juan Carvajal leg.; UPTC-R 0589, UPTC-R 0595 to 0598, UPTC-R $0600 \cdot 1$ adult ở; Santander, municipality of Sucre, La Pradera, Colegio; $05^{\circ}$ 52'05"N, 07354'15"W, 2574 m a.s.1.; 25 Jun. 2017; Diego Pérez, leg; UPTC-R $0601 \cdot 1$ adult $\widehat{\jmath}$; Santander, municipality of Sucre, La Pradera, Antenas; $05^{\circ} 51^{\prime} 20^{\prime \prime} \mathrm{N}, 073^{\circ}$ 54'14"W, 2574 m a.s.1.; 20 Aug. 2017; Diego Escamilla and leg.

Identification. Our specimens were identified as $R$. striata based on: mental scales in three pairs; scales 32-37 around midbody; dorsal scales striated, rectangular, in 33-39 transverse rows; lateral scales in 0-3 rows; ventral scales quadrangular, in 22-25 transverse rows and 10-12 longitudinal rows (Burt and Burt 1931).

Remarks. Riama striata occurred in the grassland, where it was found under logs, rocks, and moss. No individuals were detected outside of this habitat, but cryptic movements may make them difficult to detect in other habitats. We noted intra-sex differences, with males white to intense yellow ventrally (Fig. 8) and varying in size as adults; females are generally smaller than males.

Superfamily Colubroidea

Family Colubridae
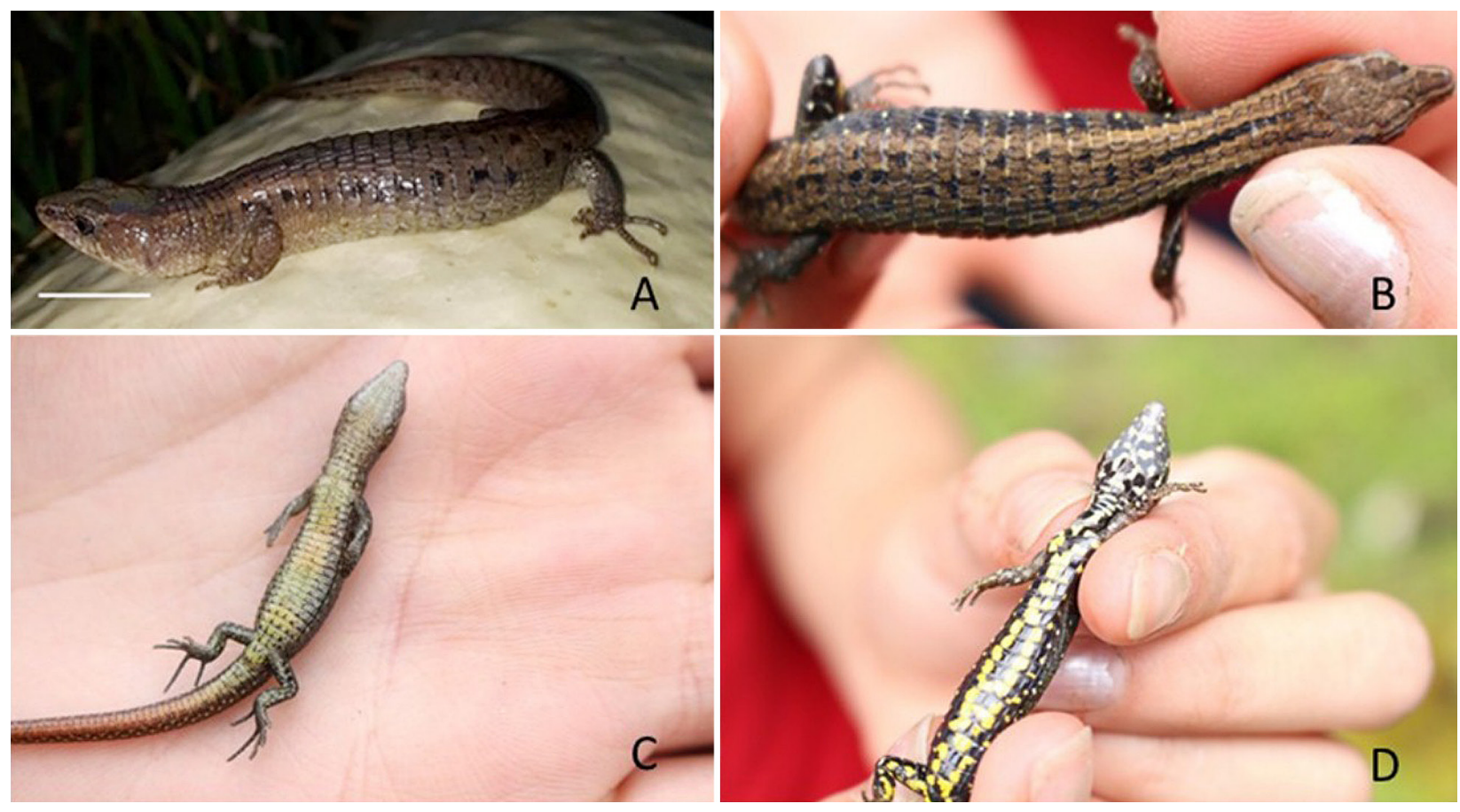

Subfamily Dipsadinae

Genus Atractus Wagler|, ¡1828

Atractus marthae Meneses-Pelayo \& Passos, 2019

Materials examined. COLOMBIA $\bullet 1$ adult $\widehat{\partial}$; Santander, municipality of Sucre, La Pradera, Fontibón; 05 51'53"N, 07354'37", 2574 m a.s.1.; 03 Feb. 2018; María Estupiñan leg.; UPTC-R 0594 - 3 adults +; Santander, municipality of Sucre, La Pradera, Colegio; $05^{\circ} 52^{\prime} 05^{\prime \prime} \mathrm{N}$,

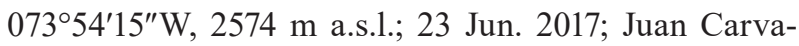
jal leg.; UPTC-R 0591 to UPTC-R 0592, UPTC-R 0602.

Identification. Atractus marthae was identified by: dorsal scale rows 17/17/17, smooth; postoculars two, loreal long, temporals 1 or 2 ; and hemipenis moderately bilobed, with lobe size equivalent to the capitulum length, semicapitated and semicalyculated (Meneses-Pelayo and Passos 2019).

Remarks. This species occurred in the grassland habitat, where it was found under rocks (Fig. 9D). No individuals were detected in other habitats (Fig. 2C), which would make their detection difficult. We observed much variation in color intrapopulation, with the ground color blackish (Fig. 9A, B) to reddish with dark longitudinal lines (Fig. 9C). In February 2018, we observed eggs and hatchlings under a fallen tree trunk, which is the first observation of reproduction for this species.

\section{Genus Erythrolamprus Wagler|, ¡1830}

\section{Erythrolamprus epinephelus (Cope, 1862)}

Materials examined. COLOMBIA • 2 adults + ; Santander, municipality of Sucre, La Pradera, La Playa; $05^{\circ}$ 52'19"N, 07354'41"W 2574 m a.s.1.; 24 Jun. 2017; Diego Pérez leg.; UPTC-R 00025.

\footnotetext{
Figure 8. Riama striata. A, B. Females (scale bar in $A=12 \mathrm{~mm}$ ). C. Ventral coloration of a female. D. Ventral coloration of a male.
} 


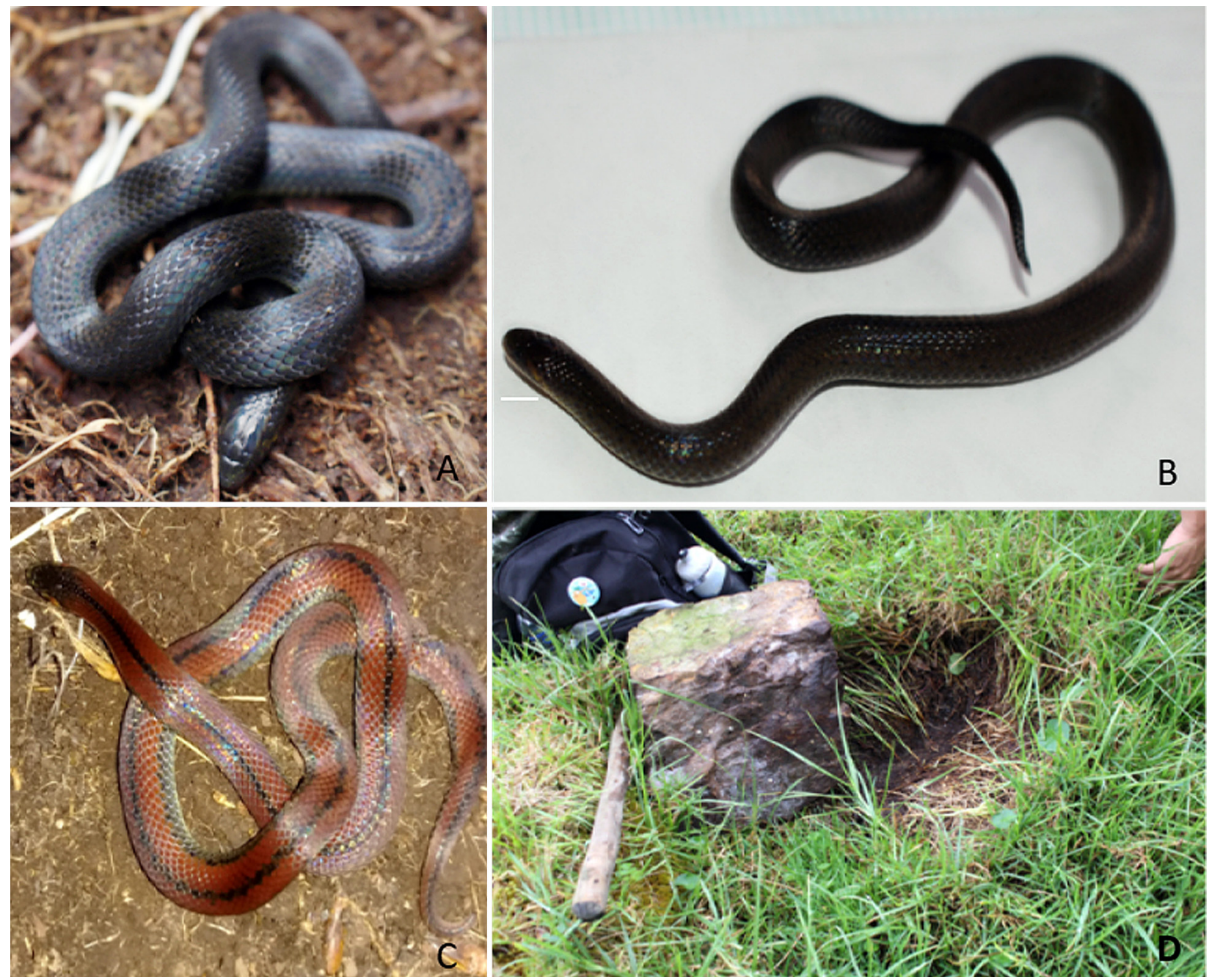

Figure 9. Atractus marthae. A, B. Black phase (scale bar in B = $8 \mathrm{~mm}$. C. Red phase. D. Preferred habitat under a stone in grassland.

Identification. Our specimen was identified as E. epinephelus based on: ventral scales 182, subcaudals 54, venter inmaculate, and scale pits present.

Remarks. We found this species in the grassland habitat, where it was under rocks (Fig. 10B), near cultivated areas with evidence of the use of agrochemicals. As an escape strategy from predators, this species can flatten the body by contracting transverse muscles (Fig.10A).

\section{Discussion}

The amphibians and reptiles that we recorded in our study area follows the ecogeographic and phylogenetic pattern identified for Colombia, where elevation and corresponding temperature and relative humidity influence the occurrence of species, mainly in Hylidae and Craugastoridae for amphibians, and Colubridae, Dactyloidae, and Gymnophthalmidae for reptiles (Castaño-Mora et al. 2000; Lynch and Rengifo 2001). These families show patterns of higher richness values within assemblies, both in highlands and in lowlands, as well as in intact and transformed habitats (Lynch 1999).

Lynch and Rengifo (2001) and Vargas-Ríos and Pedraza (2003) have reported a greater number of species in other studies in the Andean region. The transition from natural habitats to pasture and crops in the Andes may reduce species diversity, leaving only a relictual fauna, as has been documented in other high mountain (Medina-Rangel and López-Perilla 2014) and lowland regions (Carvajal-Cogollo and Urbina-Cardona 2008, 2015; Paternina-Hernández et al. 2013).

The abundance graph (Fig. 3) shows that most species, except for Dendropsophus molitor, were not abundant in the study area. Lüddecke (1997) this species was abundant due to its preferential habitats, wide food spectrum, and year-round reproduction (Guarnizo et al. 2014). These abundance patterns are characteristic of relictual assemblies for various taxa, such as mammals and amphibians (Bovendorp et al. 2018; Whiles et al. 2006). The shape of the curves shows us a hierarchy in the structure for amphibians, but for reptiles the assembly structure does not show a hierarchical pattern. The amphibians, show a general pattern to make use of resources in a differential manner (Magurran 1988, 2004).

This study is the first to document the ecology and natural history of the Endangered Hyloscirtus piceigularis (IUCN 2019) since its description by Ruiz and Lynch (1982). This species' cryptic habits and microhabitats are 

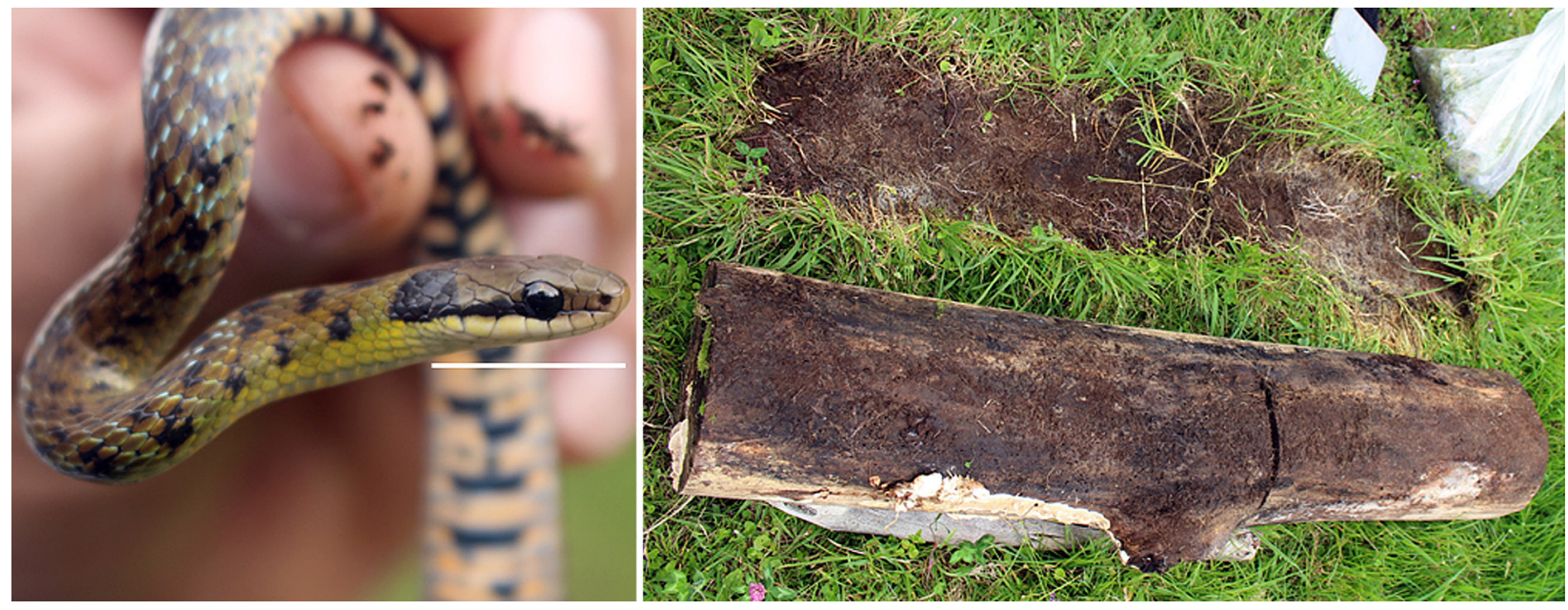

Figure 10. Erythrolamprus epinephelus and its preferred microhabitat. Scale bar (on left) = $14 \mathrm{~mm}$.

limiting factors, and habitat loss due to agriculture and livestock production is a serious threat to the survival of the species. We contribute to the ecological knowledge of Atractus marthae, the first since this species was described (Meneses-Pelayo and Passos 2019); oviposition occurs in the same microhabitat used by for concealment. This species exhibits intrapopulation variation in color pattern, which merits further study.

We recommend management strategies to conserve herpetofaunal habitats, including the maintenance of forest fragments and the stopping of agricultural and livestock expansion, which have proven to be effective in the the Santander highland, north of the Cordillera Oriental.

\section{Acknowledgements}

The Biodiversity and Conservation Group of the Universidad Pedagógica y Tecnológica de Colombia provided logistical support for our research. Diego Felipe Higuera Rojas was part of the field team. The Escamilla Quitián family welcomed us with hospitality, and community of La Pradera supported our investigation. We thank the Dr. Ross MacCulloch, academic editor, and the reviewers who greatly improved the manuscript.

\section{Authors' Contributions}

DAPR, DEQ, MFET, and JECC conceived the study and performed the fieldwork. DAPR and JECC wrote the text, confirmed the identification of all specimens, and analyzed the data.

\section{References}

Angulo A, Rueda-Almonacid JV, Rodríguez-Mahecha JV, La Marca E (2006) Técnicas de inventario y monitoreo para los anfibios de la región tropical andina. Conservación Internacional. Serie Manuales de Campo No 2. Panamericana Formas e Impresos S.A., Bogotá DC, 298 pp.

Ardila-Robayo MC, Acosta-Galvis R (2000) Anfibios. In: Rangel-Ch JO (Ed.) Colombia diversidad biótica III. La región de vida para- muna. Universidad Nacional de Colombia, Bogotá DC, 619-630. Ariza W, Carvajal-Cogollo JE, Hernández A (2010) Soacha biodiversa. Alcaldía Municipal de Soacha y Universidad Distrital Francisco José de Caldas, Bogotá DC, 180 pp.

Bovendorp RS, Brum FT, McCleery RA, Baiser B, Loyola R, Cianciaruso MV, Galetti M (2018) Defaunation and fragmentation erode small mammal diversity dimensions in tropical forests. Ecography 42 (1): 23-35. https://doi.org/10.1111/ecog.03504

Carvajal-Cogollo JE, Urbina-Cardona JN (2008) Patrones de diversidad y composición de reptiles en fragmentos de bosque seco tropical en Córdoba, Colombia. Tropical Conservation Science 1 (4): 397-416. https://doi.org/10.1177/194008290800100407

Carvajal-Cogollo JE, Urbina-Cardona JN (2015) Ecological grouping and edge effects in tropical dry forest: reptile-microenvironment relationships. Biodiversity and Conservation 24 (5): 1109-1130. https://doi.org/10.1007/s10531-014-0845-9

Castaño-Mora OV, Hernández E, Cárdenas G (2000) Reptiles. In: Rangel-C JO (Ed.) La región de vida paramuna. Colombia Diversidad Biótica III. Universidad Nacional de Colombia, Bogotá DC, 629-644.

Colwell RK (2018) EstimateS: Statistical estimation of species richness and shared species from samples. Version 7. User's guide and application. http://purl.oclc.org/estimates.

Crump ML, Scott NY (1994) Visual encounter surveys. In: Heyer W, Donnelley MA, McDiarmid RA, Hayek LC, Foster MC (Eds) Measuring and monitoring biological diversity: standard methods for amphibians. Smithsonian Institution, Washington, DC, 84-92.

Etter A, McAlpine C, Phinn S, Wilson K, Possingham H (2006) Regional patterns of agricultural land use and deforestation in $\mathrm{Co}-$ lombia. Agriculture, Ecosystems and Environment 114 (2-4): 369-386. https://doi.org/10.1016/j.agee.2005.11.013

Guarnizo CE, Armesto O, Acevedo A (2014) Dendropsophus labialis (Peters, 1863). Catálogo de anfibios y reptiles de Colombia 2: 61-70.

IUCN SSC Amphibian Specialist Group (2019) https://doi.org/10.2305/ iucn.uk.2019-2.rlts.t55601a85903067.en. Accessed on: 2019-10-15.

Lazell JD (1969) The genus Phenacosaurus (Sauria, Iguanidae). Breviora 325: 1-24

Lüddecke H (1997) Field reproductive potential of tropical high mountain Hyla labialis females: direct and indirect evidence from markrecapture data. Amphibia-Reptilia1 8: 357-368. https://doi.org/10. 1163/156853897X00413

Lynch JD, Rengifo J (2001) Guía de anfibios y reptiles de Bogotá y sus alrededores. Alcaldía Mayor de Bogotá, Departamento Técnico Administrativo del Medio Ambiente, Bogotá DC, 30 pp. 
Lynch JD (1999) Ranas pequeñas, la geometría de evolución y la especiación en los Andes colombianos. Revista de la Academia de Ciencias Exactas, Físicas y Naturales 23: 143-159.

Lynch JD, Suárez-Mayorga MA (2002) Análisis biogeográfico de los anfibios paramunos. Caldasia 24 (2): 471-480.

Magurran AE (1988) Ecological diversity and its measurement. Princeton University Press, Princeton, 179 pp.

Magurran AE (2004) Measuring biological diversity. Blackwell, Oxford, UK, $345 \mathrm{pp}$.

Medina-Rangel G, López-Perilla Y (2014) Diversidad de anfibios y reptiles en la alta montaña del suroriente de la sabana de Bogotá, Colombia. Herpetotropicos 10 (1):17-30

Méndez-Narváez J (2014) Diversidad de anfibios y reptiles en hábitats altoandinos y paramunos en la cuenca del río Fúquene, Cundinamarca, Colombia. Biota Colombiana 15 (1): 94-103

Meneses-Pelayo E, Passos P (2019) New Polychromatic Species of Atractus (Serpentes: Dipsadidae) from the Eastern Portion of the ColombianAndes. Copeia 107(2):250-261.https://doi.org/10.1643/ ch-18-163

Passos P, Lynch JD (2010) Revision of Atractus (Serpentes: Dipsadidae) from middle and upper Magdalena drainage of Colombia. Herpetological Monograph 24 (1): 149-173. https://doi.org/10.1655/ 09-041.1

Paternina-Hernández A, Carvajal-Cogollo JE, Medina-Rangel G (2013) Anfibios de las ciénagas del departamento del Cesar. In: Rangel-C. JO (Ed.) Colombia diversidad biótica XIII. Complejo cenagoso de zapatosa y ciénagas del sur del Cesar: biodiversidad, conserva- ción y manejo. Universidad Nacional de Colombia, Bogotá DC, 499-509.

Pough FH, Andrews R, Clade J, Crump M, Savitzky A, Wells K (2001) Herpetology. Second Edition. Prentice Hall, New York, 612 pp.

Rangel-C, JO (1997) Colombia diversidad biótica, la vegetación de Colombia. Universidad Nacional de Colombia, Bogotá DC, 400 pp.

Rangel-C, JO (2000) La región paramuna de Colombia y franjas aledañas. In: Rangel-C. JO (Ed.) Diversidad biótica III. Instituto de Ciencias Naturales, Universidad Nacional de Colombia, Bogotá DC, 1-23.

Ruiz-Carranza PM, Lynch JD (1982) Dos nuevas especies de Hyla (Amphibia: Anura) de Colombia, con aportes al conocimiento de Hyla bogotensis. Caldasia 13: 647-671.

Sánchez-Pacheco SJ, Aguirre-Peña V, Torres-Carvajal O (2012) Lizards of the genus Riama (Squamata: Gymnophthalmidae): the diversity in southern Ecuador revisited. South American Journal of Herpetology 7 (3): 259-275. https://doi.org/10.2994/057.007.0308 Vargas-Ríos O, Pedraza P (2003) Parque Natural Chingaza. Universidad Nacional de Colombia, Facultad de Ciencias, Departamento de Biología, COLCIENCIAS, Bogotá DC, 226 pp.

Whiles MR, Lips KR, Pringle CM, Kilham SS, Bixby RJ, Brenes R, Connelly S, Colon-Gaud JC, Hunte-Brown M, Huryn AD, Montgomery C, Peterson S (2006) The effects of amphibian population declines on the structure and function of Neotropical stream ecosystems. The Ecological Society of America, Frontiers in Ecology and the Environment 4 (1): 27-34. https://doi.org/10.1890/15409295(2006)004[0027:teoapd]2.0.co;2 